Samuel PD Anantadjaya ${ }^{1}$

School of Business, Faculty of Business

Administration \& Humanities Swiss German University,

Indonesia
ORIGINAL SCIENTIFIC ARTICLE doi:10.5937/ekonomika1502011A

Received: April 12, 2015

Accepted: May 18, 2015

Irma M. Nawangwulan ${ }^{2}$

School of Management Studies, Universitas Pembangunan Jaya, Indonesia

Ignatia Andari Pramesty ${ }^{3}$

Hilton Hotel, Bandung, Indonesia

Grace Aditya Gunawan ${ }^{4}$

Avia Tour, Jakarta, Indonesia

\title{
MEASURING CUSTOMERS' INTIMACY: EVIDENCE FROM INDONESIAN SERVICE-BASED COMPANIES
}

\begin{abstract}
Leadership is often regarded as the fuel to jump-start changes and improvement in organizations. At the same time, innovation is widely discussed as an important element in organizational development. In numerous theoretical discussions and stories of companies across the globe, successful organizational innovation depends on leadership. As the leadership pushes for innovation, the company's internal branding is expected to improve. This is particularly true for transformation leadership, perhaps. Such an internal branding is expected to shape much stronger employee-based brand equity (EBBE). Likewise, the company's innovation should enhance the customer intimacy by means of word of mouth. The relationships may not have been widely researched though the presence of technology has allowed increasing popularity in electronic communication and information sharing. Electronic word of mouth (eWOM), like testimonies, spreads insights and experiences for others. This affects customers' reactions to products and services. Service-based companies may have relied on eWOM to keep the traffic-inflows while maintaining intimacy with customers. This study attempts to analyze the relationships among transformational leadership, product/service innovation, internal branding, eWOM, EBBE, and customer intimacy in Indonesian service-based companies, such as; hotels and restaurants. A structural equation modeling is incorporated to note the simultaneous relationships.
\end{abstract}

Key words: leadership, product innovation, internal branding, electronic word of mouth, employee-based brand equity, customer intimacy

JEL classification: M31

\footnotetext{
1 ethan.eryn@gmail.com

2 inawangwulan@gmail.com

3 ignatia.pramesty@gmail.com

4 grc_gnwn@windowslive.com
} 


\title{
МЕРЕЊЕ ИНТИМНОСТИ СА КОРИСНИЦИМА: ПРИМЕР УСЛУЖНИХ КОМПАНИЈА У ИНДОНЕЗИЈИ
}

\begin{abstract}
Апстракт
На лидерство се често гледа као на гориво за промене и напредак $y$ организаиијама. Истовремено, иновацијасетретираважнимелементомуразвоју организачије. У бројним теоријским расправама и случајевима компанијама широм света, успешна иновачија зависи од лидерства. Како руководство инсистира на иновацијама, тако се очекује да се унутрашње брендирање компаније побољша. Ово се, вероватно, посебно односи на трансформационо лидерство. Од таквог интерног брендирања се очекује да обликују много већу вредност бренда засновану за запосленима (eтployee-based brand equity EBВE). Исто тако, иновачија компаније требало би да унапреди интимност са корисником услуга путем уста до уста. Ови односи нису широко истражени иако је присуство технологије омогућило повећање популарности у електронској комуникацији и размени информачија. Тзв. електронска уста (Electronic word of mоиth - еWOM) шире увид и искуства других. То утиче на реакиије корисника у вези са производима и услугама. Компаније које базирају на услугама могу да се ослоне на еWOM и да задрже одржавајућу интимност са корисником. Ово истраживање покушава да анализира односе између трансформационог лидерства, иновачије производа/ услуге, интерног брендирање, еWOM, ЕВВЕ и интимност са корисницима у услужним предузећима у Индонезији, као што су хотели и ресторани. Једно моделирање структурне релащије је искоришћено да би се фокусирала пажња на истовремене односе.
\end{abstract}

Кључне речи: лидерство, иновачије производа, интерно брендирање, електронска уста до уста, имовина у бренду заснована на запосленом, интимност са корисником

\section{Introduction}

There are numerous studies on external branding (Keller, 2013), whose focus is on delivering the organization's brand promise to customers to achieve brand equitybased customers (Keller, 2013). However, internal branding may not have been studied extensively (McKee, 2009). External and internal branding are equally necessary in delivering an organization's brand promise (Keller, 2013). In fact, fewer marketers are aware of the importance of internal branding and subsequently, a smaller number of employees believe in a company's brand promise and are endowed to delivery it (Marshall, 2013). This means that internal branding must be adopted to ensure employees recognize the fundamental branding concept to extend it to customers.

The stronger the internal branding, the faster it fosters the creation on employeebased brand equity (EBBE) (King \& Grace, 2010; King \& Grace, 2009). King and Grace (2009) introduced EBBE as "the third perspective". According to King and Grace (2009), a measurement for maintaining internal brand management is desirable, following 2 
initial perspectives in building and measuring brand equity, which are customer-based and financial-based.

From the technological perspective, it has become a public knowledge that the popularity of electronic communication is increasing along with the rapid development in the digital era. This creates an opportunity of eWOM (Cheung \& Lee, 2008). The eWOM has become an important source of information, which now can be easily obtained from any websites, and also from any social media (Chen \& Lurie, 2013; Vimaladevi \& Dhanabhakaym, 2012; Alrasheed, 2011).

In order to achieve all that, the role of human resources is extremely essential for organizations. Referring to the service-based industry, the role of human resources is even more vital to ensure the proper service delivery toward customer intimacy. Hence, suitable leadership style may be crucial to manage the pool of human resources, or otherwise known also as "human capital" (Ngah, et al., 2013). The use of a traditional leadership style that is rooted in accepting and following regulations, or the use of a transformational leadership style, which tend to motivate and inspire employees (ehotelier, 2013). Hotel industry management applies different types of leadership style and major researchers consider the transformational leadership style has a significant influence in achieving successful internal branding (Kashmiri, 2010; Kaewsurin, 2012).

\section{Literature review}

\subsection{Transformational leadership}

"I am more afraid of an army of 100 sheep led by a lion than an army of 100 lions led by a sheep" - Talleyrand (Robbins \& Judge, 2013)

The quote above represents how vital the role of a leader is in managing human resources and Burmann et al. (2009) claim that leadership is also an important aspect in the internal branding process. The most important resource in every hospitality and tourism organization is the employees themselves. The success or failure of the organization is directly influenced by how their tasks are managed and led (Hayes \& Ninemeier, 2009). Some employees genuinely love their work, whereas others just as extremely dislike them. The majority of people are somewhere in between the spectrum (Ebert \& Griffin, 2011). It is essential to identify employee behaviours, individual differences and motivation effectively before determining the most suitable leadership style applied by the managers (Robbins \& Coulter, 2009).

Previous researchers (Yukl, 2010; Ebert \& Griffin, 2011) explained different perspective approaches to studying leadership. The first perspective is from the nature of the leaders (trait approach, behavioural approach, path-goal theory, and situational approach), and the second perspective is from the followers (charismatic leadership and transformational leadership). Bernard Bass imported Burn's transforming leadership concepts from the political and social movement arena in the context of organizations (Hickman, 2010). According to Hickman (2010), Bass split Burn's link to social change from the theory of transforming leadership and adopted Burn's definition of transactional leadership to form what he characterized as transformational leadership. According to 
Bass's theory, the measurement scales of transformational leadership are (Bass, 2013):

Idealized influence to represent behaviours that stimulate strong follower emotions and identification with the leader, for instance establishing courage and dedication, and creating self-sacrifices for the followers (Yukl, 2010).

Inspirational motivationas a way to communicate an appealing vision and using symbols to focus subordinates effort and express important objectives in simple ways (Yukl, 2010; Hamilton, 2009; Bass, 2013).

Intellectual stimulation to represent behaviours that improve subordinates understanding of problem and influences them to observe problems from a new perspective (Yukl, 2010).

Individualized consideration to show sets of characteristics that provide support, encouragement, and instruction to subordinates (Yukl, 2010).

\subsection{Product innovation ${ }^{1}$}

Competition in the market has always been intense and it has become harder to control over the market (Barrows \& Powers, 2009). The combination of an interrelated and an interdependent variety of activities in marketing, to cover both the tangibility and intangibility, are crucial. Hence, the application of an extended marketing mix, which consists of: Product, Price, Place, Promotion, Process, Physical Environment, and People (Wirtz, Chew, \& Lovelock, 2012) are necessary to boost uniqueness and continuous innovation.

According to Omachu \& Einspruch (2010) there are 4 types of innovation: product innovation, process innovation, marketing innovation, and organizational innovation. Successful innovation requires an integrated design process, such as; integration in the design of the enterprise, the design of the product, as well as the design and implementation of new technologies (Preez \& Louw, 2008). According to Erdil, Erdil and Keskin (2004) there are 2 dimensions that trigger product innovation, which are:

Technological Drive/Challenges have infiltrated the way companies grow and innovate have been changed in the past decades and is still in a continual phase. Innovation process allows technology to be applied in a marketable or otherwise valuable way (White \& Bruton, 2007). The impact of technology has gone beyond its role starting from a tool to improve efficiency and effectiveness to the substitute of man power (Kandampully, 2007).

Focus on Short Time to Market pushes companies to keep-up with competitors in the wild competitive market sometimes require sooner rather than realistic sometimes made innovation only focus on short term market. It might be because of lack of time, lack of resources or staff, lack of systematic process, fear and lack of confidence about innovation since it is believed to be risky (Huseyin \& Ferit, 2007). By focusing on short term market there is an opportunity to offer valuables features which may lead to more established technologies and chances to dominate market (Chen \& Taylor, 2009).

Therefore, considering the needs on product innovation, technological drive/ challenges, and the need to time appropriately to market, the presence of transformational leadership is vital. Hence, it can be hypothesized as follows:

H1: Transformational leadership influences product innovation 


\subsection{Internal branding}

Internal branding or otherwise referred to as "internal marketing" is part of a holistic marketing concept. Internal marketing undertakes hiring, training and motivating employees to serve customers properly and it can be as vital or even more than directly marketing products or services outside the company (Kotler \& Keller, Marketing Management, 2012).

According to Kotler and Keller (2012), there are 10 types of products that marketers market, such as; goods, services, events, experiences, people, places, properties, organizations, information, and ideas. One strategy to differentiate services is to establish a brand. In contrast with a product, a brand is an extra value to a product because a brand can have different dimensions from products designed to meet the same need (Keller, 2013). Keller also explained that the differences may be rational and tangible (associated with product performance of the brand) or more emotional, symbolic and intangible (associated with what the brand represents) (Keller, 2013). Along with Keller, King and Grace (2009) agreed that branding plays a particularly significant role in the services arena. However, strong service brands are only attained when the communication of brand promise is consistent to the brand experience delivered.

The importance of internal branding in the service industries is increasing (Kaewsurin, 2012). The concept of internal branding has been defined in several ways now as a result of the growing literature on internal branding (Punjaisri \& Wilson, 2011; Kaewsurin, 2012). Punjaisri and Wilson (2011) state that internal branding is about "ensuring that the brand promise is transformed by employees into reality, reflecting the espoused brand values that set customers' expectations". Kaewsurin (2012) stated that there are 2 perspectives of internal branding;

Internal communication represents the use of internal communication tools, such as; internal publications, e-mail messages, memos, group meetings, daily briefings, direct contract, newsletters, brand books and intranet (Punjaisri \& Wilson, 2011; Kaewsurin, 2012) to influence its brand targets, who are not only customers but employees as well (Kaewsurin, 2012).

Brand training is also important in delivering brand values to employees (Almgren, Ek, \& Goransson, 2012). Brand training is a good opportunity to build understanding about brand values and to align employees to its principles and brand training should focus on creating such programs as are defined by brand values (Kaewsurin, 2012).

Therefore, the successful internal brand building requires the role of leader. The better quality of the leaders the better the internal communication and brand training. This pushes up the quality of internal branding. Hence, it can be hypothesized as follows:

H2: Transformational leadership influences internal branding

\subsection{Electronic word of mouth}

WOM communication is "oral, person-to-person communication between a receiver and a communicator whom the receiver perceives as non-commercial, regarding a brand, a product, a service or a provider" (Park, Wang, Yao, \& Kang, 2011). WOM communication plays an important role in shaping the target-customers' attitudes and behaviours towards products and firms because WOM is regarded as providing more reliable, trustworthy advice, and personal contacts are generally able to offer social 
support and encouragement (Roy, Butaney, \& Bhutaney, 2009). The emergence of the internet has transformed WOM into online WOM (Lee \& Kim, 2010), or commonly known as electronic WOM, or simply eWOM (Park, Wang, Yao, \& Kang, 2011). According to Filieri and McLeay (2013), the parameters for eWOM are;

Quality of information of eWOM has become an important influence on product evaluation since it is more believable rather than any marketers or advertisers (Lee \& Kim, 2010).

Information usefulness of eWOM has increased due to interpersonal influence across individuals. Customers with highly susceptibility to interpersonal influence are more likely to be affected by eWOM (Park, Wang, Yao, \& Kang, 2011). eWOM has shown a significant influence because of its advantages in regency, abundance and objectivity (Lee, Lee, \& Tan, 2013).

Trustworthiness refers to a set of specific beliefs dealing primarily with the benevolence, competence, and integrity of another party. Trust is important to help overcome perception of uncertainty and risk and engage "trust-related behaviour". eWOM credibility is defined as the extent to which one perceives the recommendation as believable, true, or factual. Credibility of information from social network will make customer more confidence to adopt eWOM (Park, Wang, Yao, \& Kang, 2011).

Therefore, to ensure the quality of information, information usefulness, and trustworthiness in organizations, the role of leaders is undoubtedly vital. It is expected that the transformational leadership can drive the initiatives on eWOM. Hence, it can be hypothesized as follows:

H3: Transformational leadership influences electronic words of mouth.

\subsection{Employee-based brand equity}

Supported by King and Grace $(2009 ; 2010)$ EBBEconcept, this research focuses on the foundation of EBBE, whichbehaviourand knowledge, role clarity, brand citizenship behavior, and brand commitment.

Brand knowledge is the key to create brand equity, because it creates the differential effect that drives brand equity (Keller, 2013).

Role clarity plays a vital role in organizational behaviour due to its being considered a predictor of organizational outcomes such as organizational performance, satisfaction, commitment, and turnover (Kwon, 2013). If important information about brand knowledge to achieve their performance expectations is not widely distributed, the employees' role ambiguity will increase (King \& Grace, 2009).

Brand citizenship behaviors are considered as the behavioral perspectives that measure a brand's strength (Burmann, Zeplin, \& Riley, 2009; Xiong \& King, 2013), which refer to how employees "live the brand" through their voluntary behaviors and the focus of these behaviors is the extra-role behaviors that extended beyond formal role requirement (Xiong \& King, 2013).

Brand commitment is considered as the attitudinal perspective that measures a brand's strength (Burmann, Zeplin, \& Riley, 2009; Xiong \& King, 2013), which tends to show employee's psychological attachment towards a certain brand/organization (Xiong \& King, 2013).

Therefore, it may be apparent that the creation of EBBE inside organizations may be relatively impossible without the preliminary presence of product innovation, internal 
branding, and electronic words of mouth. Hence, it can be hypothesized as follows:

H4: Product innovation influences employee-based brand equity,

H5: Internal branding influences employee-based brand equity,

H6: Electronic word of mouth influences employee-based brand equity.

\subsection{Customer intimacy}

Relationship marketing covers the entire spectrum of marketing starting from channels, business to business marketing, services marketing, marketing research, customer behaviour, marketing communications, marketing strategy, international marketing and direct marketing. Embraced by industries in the late 90's and the early 2000's, the customer relationship management (CRM) was a managerial initiative that has become the integral part of the marketing world today (Shannahan \& Shannahan, 2010). CRM is considered an important way to enhance customer loyalty and firm performance. Customer intimacy, as a part of $\mathrm{CRM}^{2}$, has a higher impact to loyalty. In the face of competitive market conditions, businesses need to deliver consumer value by having intimate relationships with customers in order to increase their loyalty. According to Simonson (2003) customer intimacy has two indicators;

Mass customization ${ }^{3}$ is about customer-centric marketing (Sheth, Sisodia, \& Sharma, 2000). Mass customization is characterized by the involvement of customers in the process before the transaction (Teerling \& Huizingh, 2006). Mass customization is generally considered as a tool to build loyalty when mass market quality is no longer a sufficient differentiator (Bhattacharya \& Bolton, 2000). A strong customer relationship is expected as the result from the combination of mass customization and the internet (Teerling \& Huizingh, 2006). The core of customization is to provide customers with personalized product based on acceptable delivery time and price not only to win customers, but also to effectively achieve the goal of sales and production in market competition.

Perceived one-to-one interaction denotes the interpersonal process which results from intimate behaviours and intimate experiences that create intimate interaction ( $\mathrm{Li}, 2009)$. In the efforts to build customer intimacy with customers, companies must learn as much as possible about each customer's behaviour, attitudes and expressed needs and use that to understand where and what pain points are in order to meet customers' expectations and retain loyalty and trust which have become more important (Williams, Hernandez, Petrosky, \& Page, 2010). With the growth of the internet, it is common these days to engage with customers in the social media. The goal of this trend is to have a constant interaction to gain greater favour for brand and enhance brand equity (Jakste \& Kuvykaite, 2012). A close relationship can be built by creating emphatic responses that can be done by appear social, personalized interface and personalized recommendation (Li, 2009).

Therefore, when the EBBE is created, employees/staff become aware and understand better about the company's brand. This is followed by a higher tendency in sharing with customers. Hence, it can be hypothesized as follows:

H7: Employee-based brand equity influences customer intimacy.

\subsection{Research model}

The major difference between the current study and many previous studies concerning the chosen variables and indicators is simply the used of those variables 
and indicators. If the previous studies tend to separate the variables and indicators, this current study attempts to combine the selected variables and indicators altogether into hotels and restaurants. Therefore, the following research model is used in this study.

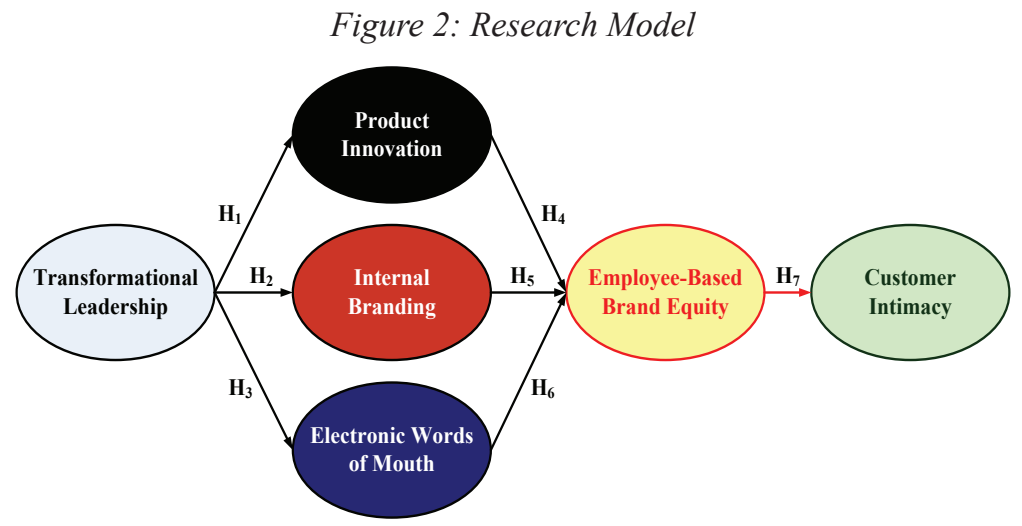

\section{Research method}

This study follows the descriptive-causal research method to provide information on certain relationships, variables and indicators (Budiman, Anantadjaya, \& Prasetyawati, 2014), and to reveal the causal effect from one variable to another as a way to measure the influence among variables (Sekaran \& Bourgie, 2013; Cooper \& Schindler, 2010).

The population is employees and customers of at least mid-scale hotels and cafes/ restaurants in the city of Jakarta and Bandung in Indonesia ${ }^{4}$. Since the nature of the selected variables used in this study is relatively leads into "internalities", the sampling method to choose hotels and restaurants follows the non-probability purposive sampling. Prior acquaintances with the hotel or restaurant management teams are certainly advantageous. A stratified sampling method is incorporated to select the supervisory level and up of all divisions of the hotels and restaurants. Despite the non-probability purposive sampling method in choosing the hotels and restaurants, the sample size calculation is performed to ensure the potential generalizability of the results. With the use of $\mathrm{PHStat}^{4}$, the minimum sample size required is 97 .

Because of the questionnaire distributions, this data will have to undergo the pretest and post-test for validity and reliability. The validity boundaries follow the SPSS' KMO \& Bartlett's Test with a minimum of 0.5 to be considered valid (Sarwono, 2012). The reliability follows the SPSS' reliability statistics, which are based on Cronbach Alpha of Standard with a minimum of 0.7 to be considered reliable (Sarwono, 2012). The hypothesis tests rely on the use of structural equation modelling with the applicable parameters on the goodness of fit (Ghozali, 2004; Santoso, 2009; Schumacker \& Lomax, 2004; Wijaya, 2009). 


\section{Data analysis}

The data is appeared to be within the acceptable boundaries of being normally distributed. With the total of 125 distributed questionnaires, only 104 questionnaires are usable due to incomplete responses, and minimal variations in responses. This represents $83.20 \%$ response rate. The descriptive statistics show that the data are generally within the acceptable parameters of normality. This indicates that the data set can be further analysed. The summary of the respondents' characteristics are as follows; approximately $58 \%$ of respondents are female, $69 \%$ of respondents are at least 35 years old or younger, $40 \%$ of respondents are residing in the suburban areas of Jakarta, $52 \%$ of respondents are holding at least an undergraduate degrees, $57 \%$ of respondents are at least holding the supervisory level positions, $81 \%$ of respondents are earning less than Rp. 10 million per annum.

In terms of the validity of the data, the following table shows 0.750 on the measure of sampling adequacy. This means that the data in this study is considered $75 \%$ valid. The reliability of the data is 0.884 . This means that the data in this study is considered $88.4 \%$ reliable for all 38 statements used in the questionnaire.

With the combination of $75 \%$ validity and $88.4 \%$ reliability, further process on data analysis can be performed.From the AMOS results, as shown in Figure 19: AMOS Output,the summaries can be drawn as follows;

1. Transformational leadership negatively influences product innovation as much as $16 \%$. Among the indicators used to approximate the transformational leadership, the inspirational motivation shows the strongest explanatory power of about $89 \%$. This result means that to create a successful transformational leadership inside organizations, inspirational motivation may have to be learnt, formulated, and implemented.

2. Transformational leadership positively influences internal branding as much as $54 \%$.

3. Transformational leadership negatively influences eWOM as much as $3 \%$.

4. Product innovation negatively influences EBBE as much as 7\%. Among the indicators used to approximate product innovation, the focus to short-time to market has the strongest explanatory power of about $80 \%$. This result means that successful product innovation relies on time to market. This simply means when organizations disregard the importance of time to market, the results of product innovation may not matter. Ironically, the average-quality product innovation may excel as long as organizations introduce the product immediately. This result means that the highest quality of product innovation may actually be wasted when organizations delay the introduction of products.

5. Internal branding positively influences EBBE as much as 33\%. Among the indicators used to approximate internal branding, brand training has the strongest explanatory power of about $74 \%$. This result means that organizations must ensure the proper and regularly-scheduled brand training to have the satisfactory internal branding. At the very least, brand training may boost employees' awareness toward the company's brand. The awareness may eventually lead to internal brand building. 
Figure 2: AMOS Output

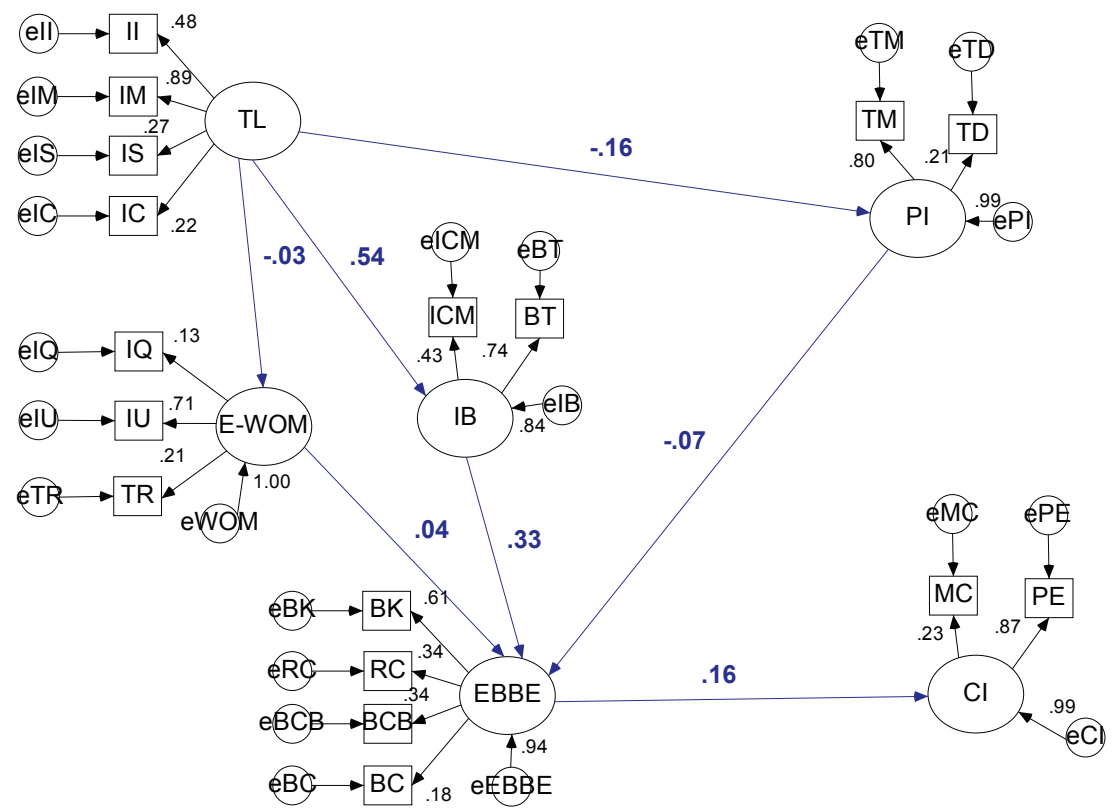

eWOM positively influences EBBE as much as 4\%. Among the indicators used to approximate eWOM, informational usefulness has the strongest explanatory power of about $71 \%$. This result means that to create a successful eWOM, the management may have to focus on the informational usefulness. Undoubtedly, the informational usefulness should be carefully approximated from the public perception, and not from the management perspective alone. This may be easier said than done. At least, this conforms to the studies on the effectiveness and efficiency on the corporate portal and search engine (Kosasih \& Anantadjaya, 2008; Perera, Anantadjaya, \& Nawangwulan, 2013).

EBBE positively influences customer intimacy as much as $16 \%$. Among the indicators used to approximate EBBE, brand knowledge has the strongest explanatory power of about $61 \%$. This result means that the management needs to focus on improving the employees' brand knowledge. With the higher employees' brand knowledge, this result shows that EBBE may improve accordingly. Concerning the customer intimacy, in the same fashion, among the indicators used, perceived one-to-one interaction has the strongest explanatory power of about $87 \%$. This result means that one-to-one interaction is vital to boost the level of customer intimacy. Hence, though personal interactions may push the organizational cost upward, it appears that the management may have to ensure such existence.

From the AMOS results, it is obvious that internal branding requires the presence of transformational leadership, and the creation of employee-based brand equity requires the presence of internal branding. Though the levels of influence are expected to be much higher, at least this provides a clear path for the management on what to do when they need to create internal branding and employee-based brand equity. It should be noted though since the level of influence of the transformational leadership toward internal 
branding is a mere $54 \%$, the formation of internal branding may be influenced by both transformational and transactional leaderships. Also, since the level of influence of internal branding toward EBBE is only $33 \%$, the management may have to investigate further other influential factors on the formation of EBBE.

\section{Conclusions and recommendations}

With the data analysis above, the following conclusions and recommendations can be formulated:

1. Transformational leadership negatively influences the processes and/or activities toward product innovation

Recommendations:

Based on this result, and concerning the intention toward product innovation, companies may need to focus on other leadership styles. As a direct opposite of the transformational leadership, perhaps, the transactional leadership serves as a better style in ensuring the proper systematic steps onto the whole processes and/or activities pushing-forth for product innovation initiatives.

Nonetheless, other leadership styles can certainly be considered. Future studies can incorporate different leadership styles, such as; authoritarian leadership, visionary leadership, situational leadership, charismatic leadership, transactional leadership, or other prominent leadership styles, to note the level of influence and/or explanatory power toward product innovation.

\section{Transformational leadership positively influences the level of internal branding}

Recommendations:

Concerning the intention to boost the level of internal branding, companies may want to ensure the proper practice of the transformational leadership. Based on AMOS' explanatory power, the use of transformational leadership inside companies may likely increase the level of internal branding by as much as $54 \%$.

Hence, it is recommended that companies may want to initiate the soft skill-based managerial training on leaderships.

3. Transformational leadership negatively influences the formation of electronic word-of-mouth

Recommendations:

Concerning the electronic word-of-mouth, and just like the intention toward product innovation, as explained above, perhaps, transformational leadership may not be the proper style to be incorporated inside companies.

Leaders with actual skills and knowledge on electronic/technology may be required to lead the team in accomplishing the success of the electronic gadgetries.

Hence, other leadership styles can certainly be considered in future studies. It is expected that other leadership styles may have higher explanatory power toward the formation of the electronic word-of-mouth, and the success stories that follows. 
4. The processes and activities of the company's product innovation negatively influence the formation of employee-based brand equity

Recommendations:

Concerning the relatively minimal value of only $7 \%$, though the result indicates that product innovation may only be indirectly influence the formation of employeebased brand equity, however, the minimal value suggests that companies may still have to focus on any intentions and initiatives on product innovation.

Hence, it is suggested that companies may pledge product innovation and encourage employees to keep working on it. The managerial pledge and encouragement may likely influence the employee-based brand equity, otherwise, in due time. With a focus on particular tangible products, the managerial commitment and encouragements could be considered as the variables on future studies.

5. The level of internal branding positively influences the formation of employeebased brand equity

Recommendations:

Companies must understand the importance of internal branding toward the formation of employee-based brand equity. To do so, companies may want to focus on continuous brand training to all employees while strengthening the quality of internal communication among staff members.

Hence, for future studies, details on brand training, including other indicators of approximate internal branding may be considered.

6. The formation of electronic word-of-mouth positively influences the formation of employee-based brand equity

Recommendations:

Concerning the electronic word-of-mouth, companies may choose to disregard if the companies are striving for more solid employee-based brand equity. Aside from a mere $4 \%$ explanatory power toward the formation of employee-based brand equity, it appears that word-of-mouth, particularly the electronic-based, may influence public/ consumers a lot more than employees of certain organizations.

Hence, on one hand, future studies may exclude the presence of electronic wordof-mouth in the model to see the variation of influential level. On the other hand, future studies may include consumer behaviour, particularly the level of intention to buy companies' products/services.

7. The formation of employee-based brand equity positively influences the level of customer intimacy toward the company's products/services

Recommendations:

With this result, it is apparent that companies need to ensure the presence of employeebased brand equity as leverage toward increasing customer intimacy. Focusing on the perceived one-to-one interaction is deemed more crucial than stressing on mass customization. It is a clear indication that personalized approaches are more advantageous.

Hence, future studies may want to focus on personalized efforts to note the impact toward the level of customer intimacy. 


\section{Bibliography}

Almgren, D., Ek, P., \& Goransson, O. (2012). The Relationship Between Internal Branding and Affective Commitment. Saarbruken, Germany: LAP Lambert Academic Publishing.

Alrasheed, M. (2011). The Impact of Online Consumer Reviews/Ratings on Consumer Behaviors and Their Purchase Decisions. Doctoral Symposium, March 2829, 2011 (pp. 1-10). West London, UK: Brunel Business School. Retrieved April 1, 2014, from http://www.brunel.ac.uk/_data/assets/file/0008/90836/ phdSimp2011MishaelAlrasheed.pdf

Barrows, C. W., \& Powers, T. (2009). Introduction to Management in the Hospitality Industry. New Jersey: John Wiley \& Sons, Inc.

Bass, B. M. (2013). Bass Transformational Leadership Theory. Retrieved December 3, 2014, from www.leadership-central.com: http:/www.leadership-central.com/ bass-transformational-leadership-theory.html\#axzz3KqAAnYLn

Bhattacharya, C. B., \& Bolton, R. N. (2000). Relationship Marketing in Mass Markets. Handbook of Relationship Marketing, 327-354.

Budiman, A., Anantadjaya, S. P., \& Prasetyawati, D. (2014, March). Does Job Satisfaction Influence Organizational Citizenship Behavior? An Empirical Study in Selected 4-Star Hotels in Jakarta, Indonesia. (M. K. Fung, Ed.) RIBER: Review of Integrated Business and Economics Research, 3(1), 130-149. Retrieved May 5, 2014, from http://sibresearch.org/uploads/2/7/9/9/2799227/riber_k14-046_130-149.pdf

Burmann, C., Zeplin, S., \& Riley, N. (2009, January). Key Determinants of Internal Brand Management Success: An Exploratory Empirical Analysis. Journal of Brand Management, 16(4), 264-284. Retrieved April 20, 2014, from http:// connection.ebscohost.com/c/articles/36282854/key-determinants-internalbrand-management-success-exploratory-empirical-analysis

Chen, H., \& Taylor, R. (2009). Exploring the Impact of Lean Management on Innovation Capability. PICMET 2009, (pp. 826-834). Portland, OR, USA.

Chen, Z., \& Lurie, N. H. (2013, August). Temporal Contiguity and Negativity Bias in the Impact of Online Word-of-Mouth. Journal of Marketing Research, 50(4), 463-476. doi:http://dx.doi.org/10.1509/jmr.12.0063

Cheung, C. M., \& Lee, M. K. (2008, August 14-17). Online Consumer Reviews: Does Negative Electronic Word-of-Mouth Hurt More? Americas Conference on Information Systems (AMCIS) (pp. 1-11). Toronto, ON, Canada: Association for Information Systems. Retrieved May 1, 2014, from http:/www.virtualcommunities.net/mediawiki/images/b/bb/Online_Consumer_Reviews.pdf

Cooper, R. D., \& Schindler, S. P. (2010). Business Research Methods (11th ed., Vol. Global Edition). USA: McGraw-Hill Higher Education.

Ebert, R. J., \& Griffin, W. R. (2011). Business Essentials (8th ed.). Upper Saddle River, NJ, USA: Pearson Education, Inc.

ehotelier. (2013, April 29). Hospitality News. Retrieved March 17, 2014, from eh: www.ehotelier.com 
Enzing, C. M., Pascucci, S., Janszen, F. H., \& Omta, O. S. (2011). Role of Open Innovation in the Short and Long Term Market Success of New Products: Evidence from the Dutch Food and Beverages Industry. Journal on Chain and Network Science, 11(3), 235-250.

Erdil, S., Erdil, O., \& Keskin, H. (2004). The Relationships Between Market Orientation, Firm Innovativeness, and Innovation Performance. Journal of Global Business and Technology, 1, 1-11.

Filieri, R., \& McLeay, F. (2013). Online Consumer Reviews: Why Do We Adopt Them? Academy of Marketing Annual Conference, (pp. 1-13).

Freund, R. J., \& Piotrowski, M. (2005). Intellectual Capital Statement - Made in Germany - and Mass Customization. 3rd Interdisciplinary World Congress on Mass Customization and Personalization, (pp. 1-6). Hong Kong, China.

Ghozali, I. (2004). Model Persamaan Struktural: Konsep dan Aplikasi dengan Program AMOS ves. 5.0. Semarang, Indonesia: Badan Penerbit Universitas Diponegoro.

Hamilton, M. (2009). The Interaction of Transactional and Transformational Leadership. (M. Erthal, C. M. Baker, D. Farazzo, J. S. Gaal, M. Kraska, R. L. Martinez, ... . M. Stock, Eds.) Online Journal of Workforce Education and Development, III(3). Retrieved April 30, 2014, from http://opensiuc.lib.siu.edu/ ojwed/vol3/iss3/4/

Hayes, D. K., \& Ninemeier, J. D. (2009). Human Resources Management in the Hospitality Industry. Hoboken, NJ, USA: John Wiley \& Sons, Inc.

Hickman, G. R. (2010). Leading Organizations Perspectives for A New Era (2nd ed.). California: SAGE Publications, Inc.

Huseyin, O., \& Ferit, O. (2007, March). An Evaluative Study of Innovation Management Practices in Turkish Firms. International Journal of Business Research, 7(2). Retrieved May 9, 2014, from http://www.freepatentsonline.com/ article/International-Journal-Business-Research/178900196.html

InterContinental Hotels Group. (2014, January 23). Brand News: New InterContinental Hotel to Open in the Third Largest City in Indonesia. Retrieved March 8, 2014, from InterContinental Hotels Group: www.ihgplc.com

Jakste, L. Z., \& Kuvykaite, R. (2012). Consumer Engagement in Social Media by Building the Brand. Electronic International Interdisciplinary Conference, (pp. 194-202).

Kaewsurin, N. (2012). An Investigation into the Relationships Between Universities' Internal Branding, Employee Brand Support and the Transformational Leadership Characteristics of Immediate Leaders: A Study from the Perspective of Academic Staffs in Thai Universities. Dissertation, Doctor of Philosophy in Marketing, Brunel Businees School. (T. C. Melewar, \& D. Yen, Eds.) Uxbridge, Middlesex, UK: Brunel University London. Retrieved March 9, 2014, from Brunel University London: http://bura.brunel.ac.uk/handle/2438/6504

Kandampully, J. A. (2007). Service Management: The New Paradigm in Hospitality. New Jersey: Pearson Education, Inc. 
Kashmiri, T. (2010, March 4). Research: Leadership in the Public Sector: Using Internal Branding as a Strategic Tool to Enhnce Public Sector Performance. Retrieved March 9, 2014, from Brunel University London: http://www.brunel. ac.uk

Keller, K. L. (2013). Strategic Brand Management: Building, Measuring and Managing Brand Equity (4th ed.). London, UK: Pearson Education Limited.

King, C., \& Grace, D. (2009). Employee Based Brand Equity: A Third Perspective. Services Marketing Quarterly, 30(2), 122-147.

King, C., \& Grace, D. (2010). Building and Measuring Employee-Based Brand Equity. European Journal of Marketing, 44(7/8), 938-971.

Kosasih, C. C., \& Anantadjaya, S. P. (2008, September). A Case Study of PT XYZ on Information and Knowledge Sharing via an Improved Corporate Portal. Jurnal Sistem Informasi, 3(2). Retrieved January 11, 2015, from http://ssrn.com/ abstract $=1357046$

Kotler, P., \& Armstrong, G. (2013). Principles of Marketing (14th ed.). London, UK: Pearson Education Limited.

Kotler, P., \& Keller, K. L. (2012). Marketing Management (14th ed.). Upper Sadle River, NJ, USA: Pearson Education, Inc.

Kwon, Y. (2013). The Influence of Employee-Based Brand Equity on the Health Supportive Environment and Culture-Organizational Citizenship Behavior Relation. Dissertation, Doctor of Philosophy in Kinesiology, University of Michigan, 1-139. (D. W. Edington, T. B. Cornwell, D. J. Harding, D. H. Kwak, \& D. J. Moore, Eds.) Ann Arbor, MI, USA: University of Michigan. Retrieved March 20, 2014, from http://deepblue.lib.umich.edu/bitstream/handle/2027.42/99914/ ybkwon_1.pdf?sequence $=1$

Lee, J., Lee, J. N., \& Tan, B. C. (2013). The Contrasting Attitudes of Reviewer and Seller in Electronic Word-of-Mouth: A Communicative Action Theory Perspective. Asia Pacific Journal of Information Systems, 23(3), 106-129.

Lee, K. T., \& Kim, S. (2010). The Effects of Valence of eWOM on Perceived Message Credibility. The Journal of Internet Electronic Commerce Research.

Li, Y. W. (2009). Personalization as a Strategy to Build Customer Relationship: The Role of Intimacy. Pacific Asia Conference on Information Systems (PACIS), Paper ID \# 97 (pp. 1-13). Hyderabad, India: AIS Electronic Library (AISeL). Retrieved May 25, 2014, from http://aisel.aisnet.org/pacis2009/97

Ling, D., \& Jiahao, Z. (2012, December). Publications and Research: Extraordinary Growth Opportunities in Indonesia for Hotel Chains. Retrieved March 8, 2014, from HVS Global Hospitality Services: www.hvs.com

Marshall, J. F. (2013, September 4). On Marketing. Retrieved March 14, 2014, from Forbes: www.forbes.com

McKee, S. (2009, December 11). Sales \& Marketing: Don't Neglet Internal Branding. Retrieved March 23, 2014, from Bloomberg Businessweek Small Business: www.businessweek.com 
Militaru, G. (2009). Technological Differentiation and Performance Measurement on Supplire Integration in New Product Development.

Ng, S., \& Hill, S. R. (2009). The Impact of Negative Word-of-Mouth in Web 2.0 on Brand Equity. ANZMAC, 9.

Ngah, H. C., Musa, M. F., Rosli, Z. N., Bakri, M. N., Zani, A. M., Ariffin, A., \& Nair, G. K. (2013). Leadership Styles of General Managers and Job Satisfication Antecedent of Middle Managers in 5-Star Hotels in Kuala Lumpur, Malaysia. Asian Social Science, 5(15), 220-226.

Omachonu, V. K., \& Einspruch, N. G. (2010). Innovation in Healthcare Delivery Systems: A Conceptual Framework. The Innovation Journal: The Public Sector Innovation Journal Vol. 15(1) Article 2, 1-20.

Park, C., Wang, Y., Yao, Y., \& Kang, Y. R. (2011). Factors Influencing eWOM Effects: Using Experience, Credibility, and Susceptibility. International Journal of Social Science and Humanity, 1(1), 74-79.

Perera, C. E., Anantadjaya, S. P., \& Nawangwulan, I. M. (2013, July). Analysis on Search Engines: Evidence of Effectiveness and Efficiency. International Journal of Management Research and Business Strategy, 2(3), 158-177. Retrieved January 11, 2015, from http://ssrn.com/abstract=2316792

Preez, N. D., \& Louw, L. (2008). A Framework for Managing the Innovation Process. Management of Engineering \& Technology, 2008. PICMET 2008. Portland International Conference, (pp. 546-558). Cape Town, South Africa.

Punjaisri, K., \& Wilson, A. (2011). Internal Branding Process: Key Mechanism, Outcomes and Moderating Factors. European Journal of Marketing, 45(9), 1521-1537.

Rahayu, S. (2011). Internal Customer Satisfaction and Service Quality Toward Trust and Word of Mouth. ASEAN Marketing Journal, 114-123.

Robbins, S. P., \& Coulter, M. (2009). Management (10th ed.). Hobokken, NJ, USA: Pearson Education, Inc.

Robbins, S. P., \& Judge, T. A. (2013). Organizational Behavior (15th ed.). Hobokken, New Jersey, USA: Pearson Education, Inc.

Roy, S. K., Butaney, G., \& Bhutaney, B. (2009). Examining the Effects of the Customer Loyalty States on the Word of Mouth. Pacific Asia Conference on Information Systems (PACIS) (pp. 1-14). AIS Electronic Library (AISeL).

RSW Creative. (2013, June 24). External Brand. Internal Brand. How Many Brands Do You Need? Retrieved March 14, 2014, from RSW: www.rswcreative.com

Santoso, S. (2009). SEM, Konsep dan Aplikasinya pada AMOS. Jakarta, Indonesia: PT Elex Media Komputindo.

Sarwono, J. (2012). Metode Riset Skripsi Pendekatan Kuantitatif Menggunakan Prosedur SPSS. Jakarta: PT Elex Media Komputindo.

Schumacker, R. E., \& Lomax, R. G. (2004). A Beginner's Guide to Structural Equation Modeling (2nd ed.). (L. E. Associates, Ed.) New Jersey, USA, USA: Inc. Publisher. 
Sekaran, U., \& Bourgie, R. (2013). Research Methods for Business: A Skill-Building Approach 6th Edition. United Kingdom: John Wiley \& Sons Ltd.

Shannahan, K. L., \& Shannahan, R. J. (2010). Strategic Orientation and Customer Relationship Management: A Contingency Framework of CRM Success. Journal of Comparative International Management, 13(1), 1-12.

Sheth, J. N., Sisodia, R. S., \& Sharma, A. (2000). The Antecedents and Consequences of Customer-Centric Marketing. Journal of the Academy of Marketing Science, 28, 54-66.

Shruthi, V. K., \& Devaraja, T. S. (2012). Customer Relationship Management as a Potential Tool for Sustained Competitive Advantage: A Study on Indian IT Industry. The International Journal of Management, 1(4), 1-18.

Simonson, I. (2003, October). Determinants of Customers' Responses to Customized Offers: Conceptual Framework and Research Propositions. Working Paper No. 1794, Stanford Graduate School of Business,. Stanford, CA, USA: Stanford University. Retrieved April 11, 2014, from http://papers.ssrn.com/sol3/papers. cfm?abstract_id $=405060$

Spreitzer, G. M. (2008). Taking Stock: A Review of More than Twenty Years of Research on Empowerment at Work. Handbook of Organizational Behavior, 5472. (J. Barling, \& C. L. Cooper, Eds.) Thousand Oaks, CA, USA: Sage.

Teerling, M.L., \& Huizingh, E. K. (2006). Exploring the Concept of Web Site Customization: Applications and Antecedents. Rijksuniversiteit Groningen, Faculteit Economie en Bedrijfskunde. Groningen: RUG: De Rijksuniversiteit Groningen. Retrieved April 20, 2014, from http://som.eldoc.ub.rug.nl/reports/themeF/2006/06F07/

The Jakarta Globe. (2013, November 14). Indonesian Hospitality Sector to Grow in 2014: Realtors. Retrieved March 8, 2014, from Berita Satu Media Holdings: www.thejakartaglobe.com

Tuuk, E. (2012, May 5). Transformational Leadership in the Coming Decade: A Response to Three Major Workplace Trends. Retrieved March 6, 2014, from Cornell HR Review: http://digitalcommons.ilr.edu/chrr/25

Vimaladevi, K., \& Dhanabhakaym, M. (2012). A Study on the Effects of Online Consumer Reviews on Purchasing Decision. Prestige International Journal of Management \& IT- Sanchayan, 1(1), 91-99.

White, M. A., \& Bruton, G. D. (2007). The Management of Technology and Innovation: A Strategic Approach. Canada: Thomson South-Western.

Wijaya. (2009). Analisis Structural Equation Modeling Menggunakan AMOS. Yogyakarta, Indonesia: Universitas Atmajaya.

Williams, K. C., Hernandez, E. H., Petrosky, A. R., \& Page, R. A. (2010). Fine-Tuning Useful E-Commerce Practices. Journal of Technology Research.

Wirtz, J., Chew, P., \& Lovelock, C. (2012). Essentials of Service Marketing (2nd ed.). Singapore, Singapore: Pearson Education South Asia Pte Ltd.

Xiong, L., \& King, C. (2013, January 1). Employee Brand Understanding: A New Perspective in Measuring the Effectiveness of Internal Brand Management. The 18th Annual Graduate Education and Graduate Student Research Conference 
in Hospitality and Tourism. Seattle. Retrieved March 6, 2014, from Marshall Digital Scholar: http://mds.marshall.edu/mgmt_faculty

Yukl, G. (2010). Leadership in Organization (7th ed.). New Jersey, USA: Pearson Education, Inc.

Endnotes:

1. Innovation concerns with change (Enzing, Pascucci, Janszen, \& Omta, 2011). There are different types of innovations such as newness of products or process, newness of usage or a combination of both and the level of difficulty in managing each type of innovation will vary (White \& Bruton, 2007).

2. CRM is a whole process where customer relations are built and maintained by delivering superior customer value and satisfaction (Wirtz, Chew, \& Lovelock, 2012)

3. Mass customization as an attempt to reach customer intimacy cannot be ended in one point because if it is ended is also means that the intimacy level which has been trying to build will be gone too.Knowledge loop of mass customization shown that how important it is to the contribution of total value which can be divided into 5 main categories (Freund \& Piotrowski, 2005): financial, innovation, processes, client/customers, and human/employees.

4. The city of Jakarta is selected due to its status as the capital city of the Republic of Indonesia. The city of Bandung is selected as the "get-away" city for the residents of Jakarta.

5. Only $50 \%$ is considered as the true potential proportion to be taken as samples. Of those $50 \%$ true proportion, the allowable sampling error is limited to be at $10 \%$ maximum, while maintaining the $95 \%$ confidence level. 